Mario Gavranović - Daniela Heilmann - Aleksandar Kapuran - Marek Verčík (Eds.): Spheres of Interaction. Contacts and Relationships between the Balkans and Adjacent Regions in the Late Bronze/Iron Age $\left(13^{\text {th }}-5^{\text {th }}\right.$ Centuries BCE). Proceedings of the Conference held at the Institute of Archaeology, Belgrade 15-17 September, 2017. Perspectives on Balkan Archaeology. Volume 1. Verlag Marie Leidorf $\mathrm{GmbH}$, Rahden/Westf. Leidorf 2020. 316 strán. ISBN 978-3-86757-110-4, ISSN 2700-1253.

Do rúk sa nám dostala publikácia z novej série s titulom „Perspectives on Balkan Archaeology (PeBA)“. Uvedenú edíciu v predslove $(s .7,8)$ bližšie predstavujú jej editori, renomovaní špecialisti na pravekú a klasickú archeológiu, Carola Metzner-Nebelsicková, Peter Pavúk a Barbara Horejsová. Prvý zväzok „pohl’adov na balkánsku archeológiu“ obsahuje príspevky účastníkov v poradí druhej konferencie s názvom zhodným so sériou a na tému „Sféry interakcie. Kontakty a vzt’ahy medzi balkánskymi a susediacimi regiónmi v mladšej dobe bronzovej až dobe železnej”. Uskutočnila sa na Archeologickom ústave v Belehrade (Srbsko) v septembri 2017. Recenzovanú publikáciu zostavila štvorica európskych bádatelov - Mario Gavranović, Daniela Heilmannová, Aleksandar Kapuran a Marek Verčík, ktorým sú širšie balkánsko-európske spojitosti v pravekej archeológii vel'mi dobre známe.

V prológu (s. 9) čitatel’ov pozdravil Rastko Vasić - žijúca legenda balkánskej archeológie. Úvod s dodatkom „l'udia, kultúry, vzájomné pôsobenie" (Mario Gavranović, Daniela Heilmannová, Marek Verčík; s. 11-20) oboznamuje nielen s nosnými okruhmi, ktorým sa príspevky z vyššie spomenutej konferencie o "sférach interakcií" venujú, ale aj s ich chronologickým rámcom, ktorým je na analyzovaných teritóriách začiatok doby bronzovej až záver doby železnej (r. 2000-500 pred n. 1.). Možno podotknút, že sledovaný priestor je geograficky vcelku rozsiahly a patrí doň aj Karpatská kotlina. Samotný úvod trojice z editorov tohto zväzku je zároveň prehladom obsahu predloženej publikácie a prináša dôležité poznámky k aktuálnym problémom bádania o dobe bronzovej a železnej na Balkáne. Aj preto si v nasledujúcich riadkoch nekladiem za ciel's jednotlivými bádatel'mi polemizovat', ale skôr novú zahraničnú edíciu a jej prvý zväzok uviest’ do povedomia slovenským archeológom. Obsahuje 14 recenzovaných príspevkov, ktoré predložili 19 bádatelia. Všetky články sú zverejnené v anglickom jazyku a na začiatku každého je trojjazyčný súhrn.

Maja Goriová a Tobias Krapf priblížili „Výzvy a možnost' použitia sietovej analýzy vo výskume interakcií na juhozápadnom Balkáne v strednej a mladšej dobe bronzovej“ (s. 21-35). Východiskom k diskusii o vhodnosti aplikovania sietovej analýzy (angl. Network Analysis) na archeologický materiál z vybranej oblasti Balkánu je podl’a autorov uspokojivo preskúmaná sídlisková lokalita Sovjan na juhovýchode Albánska, na ktorej sa okrem iného doložilo kontinuálne osídlenie od začiatku doby bronzovej až po včasnú dobu železnú. Keramický materiál a doklady medziregionálnych vplyvov z tohto sídliska spoločne s d’alšími súvekými nálezmi z jazernatého regiónu medzi súčasným Albánskom, Gréckom a Severným Macedónskom umožnili analyzovat konektivitu pravekých komunít, a to v odlišných priestorových (mikroregionálnych - makroregionálnych) a časových úrovniach. Z príspevku je napr. evidentné, že siet' kontaktov lokality Sovjan zo staršej doby bronzovej je odlišná od siete kontaktov, ktorú dokumentuje materiál zo strednej, no najmä z mladšej doby bronzovej.

„Podobnosti a odlišnosti v materiálnej kultúre skupiny Belegiš II-Gáva na juhu Panónskej panvy a v povodí rieky Morava“ (s. 37-52) sa podujali osvetlit Aleksandar Kapuran a Aleksandar Bulatović. Treba uznat, že proces i jednotlivé fázy kultúrneho ovplyvňovania sa komunít s charakteristickou "žliabkovanou keramikou“ z juhu Karpatskej kotliny a zo stredného Balkánu sú podstatne zretelnejšie vd’aka terénnym výskumom z posledných dvoch desatročí, a zvlášt v povodiach riek Vel'ká a Južná Morava. K lepšiemu poznaniu chronologického postavenia viacerých dlhšie osídlených sídlisk/hradísk v povodí Moravy prispeli najmä nové absolútne dáta, čím sa zároveň korigoval pohlad na všeobecne akceptovaný systém chronológie mladšieho praveku na strednom Balkáne. Autori vo svetle nových nálezov charakterizujú kultúrny komplex Belegiš II-Gáva, ale aj diskutujú argumenty, ktoré sú bud' za, alebo proti klasickej hypotéze o migrantoch z egejskej oblasti v pracovnom priestore.

Mario Gavranović a Daria Ložnjak-Dizdarová v zdramatizovanom názve článku „Spálit’, alebo nespálit: inhumácia verzus kremácia na konci doby bronzovej v oblasti medzi juhom Karpatskej kotliny a západným Balkánom“ (s. 53-74) naznačujú, že sa bližšie pozreli na dualitu pohrebného rítu tamojších populácií z 11.-8. stor. pred n. l. Zameriavajú sa tak na juhovýchodnú okrajovú zónu civilizácie popolnicových polí s dominanciou kremácie v pohrebnom ríte, ako aj na oblast’ západného Balkánu s kontinuálne používanou inhumáciou. Výber pohrebného rítu, samozrejme, na dotknutom území Balkánu podmieňovalo viacero faktorov či osobité priority. Vzájomný dopad odlišných pohrebných rítov na susediace spoločenstvá - t. j. komunity na západnom Balkáne praktizujúce inhumáciu a populácie z juhu Karpatskej kotliny preferujúce kremáciu, sa zvlášt prejavil v 9.-8. stor. pred n. 1. výskytom vel’kých birituálnych pohrebísk v hraničnej zóne pozdíž Sávy. V tomto kontexte sa autori zmieňujú aj o prvých mohylových hroboch, ktoré sa objavili v závere sledovaného obdobia na vybraných pohrebiskách.

„Stredná Dalmácia v mladšej dobe bronzovej až včasnej dobe železnej vo sfére interakcie medzi Karpatskou kotlinou, Apeninským polostrovom a Egeidou“ (s. 75-93) bola predmetom záujmu Sabiny Pabstovej. Hoci stav výskumu 
tejto oblasti na východe Jadranu neumožňuje komplexné bádanie, vybrané nálezy indikujú pozoruhodné nadregionálne spojitosti. Napríklad v mladšej dobe bronzovej na danom území aj severozápadnom Balkáne autorka pozoruje zjavné vplyvy z Karpatskej kotliny, čo dokumentuje istými typmi bronzových zbraní a ozdôb. Pravda, viaceré z kovových predmetov s vnútrokarpatským pôvodom sa rozšírili aj v iných regiónoch Balkánu, Itálie a Grécka. Miesta sledovaných nálezov zároveň poukazujú na trasy kontaktov (resp. migrácie súvekého obyvatel'stva), ktoré v niektorých prípadoch neboli iba jednosmerné. Na prelome doby bronzovej a železnej, t. j. 11./10. stor. pred n. 1., sa analyzované komunikačné spojenia sčasti zmenili, prípadne nadobudli odlišný charakter (napr. so severozápadom Grécka a strednou Itáliou).

Katalin Jankovitsová sa upriamila na „Kontakty medzi Zadunajskom, Balkánom, severnou Itáliou a Gréckom v mladšej dobe bronzovej odzrkadlené v ochrannej zbroji“ (s. 95-113). Nástup účinnej obrannej výzbroje z bronzu, ku ktorej patrili pancier, prilba, náholenice a štít, je vo viacerých regiónoch Európy všeobecne spojený s používaním útočných zbraní, zvlášt dlhých bronzových mečov. Autorka postupne v širších teritoriálnych súvislostiach sleduje distribúciu bronzových plechových náholeníc a dvojdielnych pancierov, ich vzájomné podobnosti/odlišnosti (vrátane detailov remeselného vyhotovenia a výzdoby) či chronologický rámec. Nezabúda sa ani na známe nálezy zo stredného Podunajska a Slovenska, napr. z mohyly v Čake. Niet pochýb, že analyzovaná ochranná zbroj umožňuje premýšlat o interakciách medzi súvekou vojenskou aristokraciou a elitami mladšej doby bronzovej vôbec. V kontaktoch sa však môže odrážat' aj dial'kový obchod, osobná angažovanost' a interakcie obchodníkov alebo aktivity tzv. potulných remeselníkov-špecialistov, ktorí sa pohybovali medzi centrálnymi lokalitami spracovávajúcich kovy.

Ďalší článok predstavuje „Sídlisko Čepinci (Sofia, Bulharsko) v kontexte mladšej doby bronzovej na strednom Balkáne" (Tanya Hristova, s. 115-139). Toto sídlisko sa objavilo v roku 2015 a na jeho ploche sa preskúmalo 157 objektov niekol'kých typov vrátane obydlí. Autorka opisuje charakteristické štruktúry a na základe ich priestorovej analýzy a identifikovaných aktivít uvažuje o najmenej dvoch obytných areáloch so zázemím, ako aj o priestore neobytného charakteru. Rozbor keramiky, bronzy a komparácia s d'alšími náleziskami na strednom Balkáne dovolujú túto sídliskovú lokalitu datovat’ od polovice 13. až po záver 12. stor. pred n. l., eventuálne ju spojit’ s osídlením kultúry Brnjica. Za zmienku stojí, že sídlisku v Čepinci sa pripisuje dôležité miesto $v$ procese šírenia žliabkovanej keramiky na území dnešného Bulharska. Aj toto potvrdzuje, že tento keramický štýl, samozrejme, že v kombinácii s lokálnymi osobitostami v keramickom repertoári, formoval kultúrny charakter stredného a východného Balkánu na sklonku 2. tisícročia pred n. 1 .

Aleksandra Papazovska vyhodnotila „Sídliská z včasnej doby železnej v Macedónsku a ich vzt’ah k pohrebiskám“ (s. 141-153). Záver doby bronzovej a tzv. prechodné obdobie na teritóriu Macedónska boli turbulentnou érou, ktorú sprevádzalo aj zakladanie nových sídlisk. Autorka generalizuje architektúru i s celou škálou archeologicky rozpoznaných prvkov, ale aj špecifiká osídlenia a spôsobu života vo včasnej dobe železnej. Známe sídliskové lokality popri tom konfrontuje so súvekými pohrebiskami, plochými aj mohylového typu. Príspevok zdôrazňuje, že sociálno-ekonomické podmienky komunít zo začiatku doby železnej charakterizuje objavenie a rozšírenie sa nového kovu - železa. Železná metalurgia ovplyvnila rozvoj remesiel, obchodu a vzrast kultúrnej úrovne vôbec. Nové aspekty života $\mathrm{v}$ dobe železnej vytvorili na sledovanom území výhodné podmienky pre vznik silných komunít a rozvoj protourbánnych centier, ktorých vývoj pokračoval v historickom období.

„Morské národy a diskusia o ,balkanizme‘ v archeológii mladšej doby bronzovej" (s. 155-176). Takto nazvali svoj príspevok Uroš Matić a Filip Franković. Podotýkajú, že jednou z často diskutovaných tém v pravekej archeológii juhovýchodnej Európy je predpokladaný pohyb početnej populácie z Balkánu, resp. až niekol'kých migračných vín, ktoré v mladšej dobe bronzovej zasiahli východné Stredomorie a zdevastovali tamojšie kultúrne centrá. Títo migranti sú v spisbe uvádzaní ako proto-Ilýri, Ilýri, Dáko-Mýzijci, Mýzijci, Dardani, Frýgovia, prípadne nositelia kultúry popolnicových polí. Ich archeologické "stopovanie" a identifikácia však nie sú bezproblémové. Problematické sa ukazuje aj stotožnenie vybraných artefaktov, napr. spôn typu Peschiera, s morskými národmi na dobových reliéfnych zobrazeniach v Egypte a pod. Autori preto archeologický „,balkanizmus“ tohto typu kritizujú a sú za dekonštrukciu názoru o pôvode morských národov vo vnútrozemí Balkánu, či ich zjavnej participácii na migráciách. Zásadné argumenty podporujúce balkánske korene fenoménu morských národov totiž absentujú.

Marija Ljuština a Katarina Dmitrovićová vnášajú „Trochu svetla do temného obdobia“ a prikladajú k tomu „Poznámky ku kultúrnej kontinuite mladšej doby bronzovej až včasnej doby železnej na západe povodia Moravy" (s. 177-188). Autorky sa k pertraktovanej téme vyjadrili prostredníctvom štúdia pohrebísk, ležiacich na odlahlom okraji „sveta popolnicových polí“. V zmienenej oblasti na západe Srbska je v praveku všeobecne známa tradícia pochovávania na mohylových pohrebiskách. Avšak poznatky o pohrebnom ríte mladšej doby bronzovej a tzv. prechodného obdobia sú podla nich zlomkovité, a na komplexnú rekonštrukciu situácie v tejto oblasti na prelome 2. a 1. tisícročia pred n. l. nedostatočné. Príspevok uvádza viaceré lokality zo sledovaného časového úseku, na ktorých je doložená bud' kremácia, alebo inhumácia, a ktoré dokumentujú kontinuitu a v mnohých prípadoch konzervatívny prístup k pohrebnému rítu. Zdá sa, že pretrvávanie istých kultúrnych prejavov súvisí s geografickou pozíciou týchto lokalít a vzdialenostou kultúrnych centier.

Titulom „Spojitosti medzi juhovýchodom Karpatskej kotliny, západným a stredným Balkánom v mladšej dobe halštatskej: krásne dámy z juhu“ (s. 189-215) do publikácie prispel Marko Dizdar. Autor podrobnejšie analyzuje okruh nálezov, ktoré reprezentujú ženský šperk (vrátane jeho osobitých kombinácií), kroj a ženu ako archeologicky jasne viditel'nú rodovú skupinu vôbec. Uvedené kombinácie ozdôb indikujú aj rôzne komunikačné spojenia juhovýchodu Karpatskej kotliny. Nálezy bronzových prelamovaných opaskových garnitúr a isté tvary spôn ukazujú napr. na kontakty s komunitami na severe Balkánu v druhej polovici 7. stor. a na začiatku 6. stor. pred n. 1 . Od počiatku 6. stor. pred n. 1. je vidiet’ aj intenzifikáciu kontaktov so západným a stredným Balkánom, čo autor dokladá tiež prostredníctvom opaskov a spôn. Predpokladá, že tieto predmety sa v sledovanej oblasti neobjavili len vd’aka bežným kultúrnym kontaktom a vplyvom, ale pravdepo- 
dobne aj prostredníctvom mobility žien, ktoré prišli na juhovýchod Karpatskej kotliny v mladšej dobe halštatskej zo susedných oblastí.

Rovena Kurtiová sa zamerala na „Všeobecné trendy a regionálne špecifiká doby železnej na západnom Balkáne: ženské ozdoby opaska v 7.-6. stor. pred n. 1. na severe Albánska“ (s. 217-252). Príspevok je súhrnom poznatkov o ozdobách opaska vo vymedzenom období a vybraných regiónoch Albánska. Analýzou jednotlivých kategórií opaskov a záveskov, dôležitých regionálnych markerov, autorka poukazuje na podobnosti/odlišnosti a vztahy medzi súvekými spoločenstvami v pracovnom priestore, ale neobchádza ani iné aspekty vrátane zákonitostí pohrebného rítu a pod. Domnieva sa, že vzrast rozmanitosti ženských opaskových ozdôb, prípadne ich spojitost’ s inými šperkami, svedčí o náraste sociálnej komplexnosti, čo podporujú nálezové súbory tohto typu z mohýl doby železnej. Odhliadnuc od regionálnych špecifík týchto kategórií predmetov autorka prostredníctvom nich konštatuje zložitejšie formy sociálnej interakcie aj d’alekosiahle kontakty (s teritóriami Macedónska, so stredojadranskou oblastou Itálie či s okruhom halštatskej kultúry v širšej strednej Európe).

„Vztahy Balkánu s Egeidou: na prípade pohrebného rítu doby železnej v severnom Grécku“ (s. 253-269) sa podujala osvetlit Anne-Zahra Chemsseddohová. Konštatuje, že sever Grécka je podnetnou oblastou na sledovanie kultúrnych kontaktov, čo vyplýva i z jeho geografickej polohy. Severojužné kontakty sú zjavné tak v mladšej dobe bronzovej, ako aj vo včasnej dobe železnej či v archaickom období sprevádzanom gréckou kolonizáciou. Autorka sa zmieňuje, že bádatelia jednotlivým regiónom na severe Grécka pripisujú rôzne poslanie: spravidla koridor sever-juh, periféria bud' gréckeho sveta, alebo stredného Balkánu. Archeologický materiál svedčí o tom, že tento priestor bol dejiskom zložitých kultúrnych vztahov medzi komunitami usadenými na strednom Balkáne a obyvatel’stvom južného Grécka, čo sa prejavuje rôznymi spôsobmi, závislými od analyzovaných nálezov, resp. sfér ludských aktivít. Príspevok, samozrejme, tieto interakcie sleduje v medziach pohrebného rítu včasnej doby železnej (11.-7. stor. pred n. 1.) na území medzi pohorím Pindos a juhozápadom pohoria Rodopy.

Článok Anny Pantiovej je výstižným pohladom na „Monochromatickú keramiku: typológiu, výrobu a rozšírenie v severnom Grécku od neskorogeometrického do archaického obdobia" (s. 271-294). Jednofarebná keramika je bežná najmä v sídliskových nálezoch z doby železnej v pobrežnej oblasti Solúnskeho zálivu, no nechýba ani na lokalitách vo vnútrozemí. Všeobecne sa delí do dvoch kategórií: na hrubostennú a tenkostennú. Najjemnejšie výrobky sú „hrúbky vajcovej škrupiny“ (angl. so-called 'egg-shelled' pottery). Výroba monochro- matickej keramiky sa datuje od 8. do konca 6. stor. pred n. 1. Autorka vysvetluje špecifiká produkcie tohto riadu, opisuje najrozšírenejšie tvary a charakteristickú výzdobu. Súveké populácie túto keramiku obvykle používali v rámci „sympózií“ a patria sem napr. šálky bez nôžky, jednouché fialé alebo olpai. Jednofarebná keramika zrejme $\mathrm{v}$ sledovanom priestore $\mathrm{v}$ mladogeometrickom období suplovala skyfoi a jej výroba sa zastavila, ked' začal vo väčšom množstve prichádzat’ do miestnych obchodov atický a korintský keramický tovar.

Posledný zo štrnástich príspevkov približuje „Skúmanie medziregionálnych vplyvov a životných cyklov dvoch kovových nádob použitých ako urny $\mathrm{v}$ intra muros hrobe zo 4. stor. pred n. 1. vo Vergine/Aegae" (Athanasia Kyriakouová; s. 295-315). V historicky známom meste Aegae (Vergina, sever Grécka) sa napriek existencii vel'kej nekropoly s honosnými hrobovými architektúrami a mimoriadne vybavenými hrobmi evidujú d’alšie tri hroby, ktoré boli uložené vo verejnej časti tohto starovekého mesta, konkrétne vo svätyni Eukleie. Vzhladom na ich bohatý inventár niet pochýb, že sú pohrebmi elít starovekého Macedónska. Autorka bližšie skúma dvojicu kovových nádob-bronzovú valcovitú cistu a zlatú pyxidu, ktoré boli $\mathrm{v}$ jednom $\mathrm{z}$ týchto troch hrobov. Podla analýzy spálených kostí patrili dospelému mužovi a datované sú do záveru 4. stor. pred n. 1. Štúdia hladá nielen podobnosti k týmto dvom unikátnym artefaktom vo zverejnených kovových nádobách z Macedónska a iných krajín, ale aj pátra po aktéroch, ktorí participovali na výrobe či požívaní skúmaných nádob.

Možno zhrnút, že prvý zväzok zo série „PeBA“ predstavuje komplet širokého archeologického spektra otázok a, samozrejme, aj odpovedí z nemenej širokého územia Balkánu (vrátane súčasného Albánska, Chorvátska, Srbska, Bosny a Hercegoviny, Bulharska, Macedónska či Grécka s prilahlou Egeidou), no najmä pohladov na interakcie tejto časti Európy s okolitým svetom (tažiskovo) v 13.-5. stor. pred n. l., v ktorom hrala dôležitú rolu aj Karpatská kotlina. Treba zdôraznit,, že ide o štúdie špecialistov, ktorí sa systematicky zaoberajú archeologickou problematikou Balkánu, prípadne východného Stredomoria. „Sféry interakcie“ sú základným kameňom nového radu publikácií, ktorý má šancu byt๋ užitočnou profesionálnou platformou tak na kooperáciu (nielen) balkánskych bádatelov, ako aj rozširovanie pohladov na archeológiu juhovýchodnej Európy.

\section{Vladimír Mitáš}

Príspevok vnikol s podporou grantového projektu APVV 16-0441 "Prínos Slovenska k hospodárskemu a spoločenskému rozvoju stredoeurópskych popolnicových poli".

DOI: https://doi.org/10.31577/slovarch.2021.69.17 